\title{
STUDY OF LEVELS OF READINESS OF FUTURE SPECIALISTS OF PHYSICAL CULTURE FOR HEALTH PRESERVATION OF STUDENTS
}

\author{
Petr Dzhurinsky
}

It has been established, that the training of future physical culture specialists for health preservation of students in the context of the development of education in Ukraine is characterized by active innovative shifts, associated with the formation of the content of new higher education, in connection with which its purpose is expanding and changing. Health preservation and health-preserving technologies constitute one of the most promising educational systems.

It has been determined, that today the development of a comprehensive program of a higher educational institution is urgent, which would allow solving problems of creating conditions, conducive to preservation and strengthening of health; introduction of a methodology, principles and methods of health-preserving education, software and hardware tools for monitoring, shaping, developing and maintaining the health of participants in the educational process; control over the observance of legislative and regulatory legal acts, regulating the activities of an educational institution on the issues of health preservation.

It is believed, that health-preserving activity of physical culture specialists is a set of actions, operations and procedures that functionally and technologically ensure the achievement of a result in maintaining and strengthening health. We understand health-preserving activity as a professional property, which expresses the degree of assimilation of social experience in the field of ensuring education and health of students by means of physical culture by a future specialist, as well as the ability to use this experience in professional activity. The most significant structural components of the readiness of future physical culture specialists for health preservation of students have been revealed, namely: motivational and creative components. The levels of the readiness of the subjects for the motivational, cognitive, activity, creative and organizational and educational aspects have been determined

Keywords: professional training, structural components, readiness level, health preservation, future specialists

How to cite:

Dzhurinsky, P. (2021). Study of levels of readiness of future specialists of physical culture for health preservation of students. ScienceRise: Pedagogical Education, 5 (44), 30-33. doi: http://doi.org/10.15587/2519-4984.2021.241256

(C) The Author(s) 2021

This is an open access article under the Creative Commons CC BY license hydrate

\section{Introduction}

The implementation of a new paradigm of higher education requires new approaches to the study and scientific and methodological developments of science. Improving the quality of training of future professionals is the most important socio-cultural problem, which is largely due to the processes of democratization, innovation, technology and the need for positive change in society for individual human development, self-realization in the environment.

L. Sushchenko points out the urgency of research on the problem of professional training of future specialists in physical education in modern conditions.

The scientist believes that "deep socio-economic transformations of society, economic development on a market basis, the emergence of the labor market and the growth of the educational services sector requires qualitative changes in the conceptual framework of training, retraining and advanced training of physical education" [1].

The development of new approaches to improving the system of professional training of future specialists in physical culture and sports in order to increase their competitiveness, ready for continuous professional de- velopment, able to strengthen and educate students physically, is important and necessary. The future specialist in physical education, conducting physical culture and health and sports events, must not only have the necessary knowledge and skills, but also be able to use them, taking into account their age, health and individual characteristics, features of the internal and external environment.

The training of future specialists in physical education today is characterized by changes, associated with the formation of a new content of higher education, which changes the purpose and expands the capabilities of future professionals. Health-preserving technologies are one of the most relevant in the training of a modern specialist in physical education.

An analysis of the problem of training future professionals in physical culture and sports for health preservation of students has shown that scientists do not pay enough attention to this problem.

\section{Literary review}

Some aspects of the peculiarities of the training of specialists in physical culture and sports are based on the principles of the National Doctrine of the Development 
of Physical Culture and Sports (2004); Law of Ukraine "On Higher Education" (2014); Concepts of the State target social program for the development of physical culture and sports (2015); National Strategy for Physical Activity in Ukraine for the period up to 2025 "Physical activity - healthy lifestyle - healthy nation" (2016) [2].

In Ukraine, the orientation of the education system determines the need to prepare applicants for higher education institutions in accordance with today's social and economic demands. In the process of training, applicants must master the values of health and well-being, healthy lifestyle, physical education at a level that would ensure the optimal level of the readiness to use the means of physical culture and in professional activities. The strategy for the development of the education system envisages improving people's health and creating conditions for physical education. The main builder of their health is the person him/herself, and maintaining a healthy lifestyle, sufficient physical activity, should have the support of the population and the state [3].

The problem of insufficient motor activity is urgent in some western countries, so in the Netherlands very often physical education, especially in primary school is not given due attention. Only since 2014, the Dutch Inspectorate of Education has developed principles for the distribution of hours for physical education for different types of secondary schools [4].

Logically and systematically develop the system of physical education and rehabilitation of schoolchildren in German schools. In most German regions, there is a distribution of teacher training depending on the type of school. Peculiarities of training depend on the type of school, in which the future physical education teacher will have the right to work: primary school, secondary school, vocational school and higher school, a separate type of school is a school for children with special needs [5].

The scientific and methodological approach to the problem of health care should be associated with the training of future specialists in physical culture in higher education [6].

Attempts to comprehend the accumulated theoretical and applied developments on the problem of forming a healthy lifestyle in science are carried out repeatedly by domestic scientists. However, according to many researchers, only in the last century there was a real basis for their generalization and systematization, which allowed for an in-depth analysis of the essence of this phenomenon, the disclosure of the scientific meaning of "healthy lifestyle"; The fundamental basis in the development of the problem of human health is the research, carried out during the consideration of the laws of individual human health and healthy lifestyle.High mental load, lack of motor activity negatively affect the vital functions of organs and functional systems of the body of students. To solve health problems, the motor regime should be interdependent with other components of the general regime, where learning should be replaced by active recreation in the classroom, after school and extracurricular time, which will increase the efficiency of students and their learning. All this determines the healthpreserving functions of a specialist in physical culture and sports in a secondary school. In order to carry out health care activities with students, a professional must be prepared for such activities. In our opinion, the structure of health activities of the future specialist in physical culture and sports includes the following components: physical activity of the individual; system of healthimproving physical exercises; sports and mass work; physical culture and health work; hardening of the body; mobile and sports games [7].

The value of health is seen as key, as the health of a nation as a whole depends on the health of each of its citizens and is a condition for the survival of society [8].

An important role in a healthy educational space is played by both the material base of the educational institution and the specific purposeful work, carried out by the administration and teaching staff. Adequacy of educational and extracurricular workload of students, age-appropriate approach to the choice of forms and means of educational, preventive and physical culture and health work - the reserves that are available to improve working and leisure conditions of students, on which their psychophysical health depends [9].

It is important to develop a comprehensive program of higher education, which would solve the problem of creating conditions, conducive to maintaining and promoting health; introduction of methodology, principles and methods of health education, software and hardware for monitoring, formation, development and preservation of health of participants in the educational process; monitoring compliance with laws and regulations, governing the activities of the educational institution on health issues. The research of scientists attracts the attention to the fact that the preparation of students for the organization of healthy leisure is a type of educational activity of students, which aims to form the readiness for this work. Students' readiness to organize healthy leisure is considered as a set of interests in the problems of student health in leisure time, a system of theoretically oriented and applied knowledge about the nature and structure of this phenomenon, skills of design and introduction of educational arrangements for the optimal development of mental value, cognitive and physical components of health-preserving leisure.Thus, it is possible to state the existence of a certain scientific fund on health issues. Some scientists believe, that the health activities of physical education professionals are a set of actions, operations and procedures, that functionally, technologically ensure the achievement of results in maintaining and promoting health. Health-preserving activity is understood as a professional property, which expresses the degree of assimilation of social experience in the field of parity of education and health of students by means of physical culture by a future specialist and the ability to use this experience in professional activities [10].

There are five main areas of health activities: physical education, which is due to the importance of physical education, the development of fitness physical qualities, that form the potential of physical health; medical - associated with the need to accompany students, to diagnose health, with the analysis and development of recommendations, the adoption of preventive and curative measures; educational-valeological - is determined by the increase of valeological education of the subjects of the educational process; psychological - due to the need for psychological and pedagogical support of stu- 
dents through the development and correction of systemically and individually oriented programs and ensuring a healthy mode of work, rest in the institution; information determined by the need for prompt processing, systematization and storage of information about the health of participants in the educational process [11].

These areas of work create a health-preserving educational space, which involves the integration of health-preserving activities in the educational process, the development of integrated courses, increased physical activity for those involved, a systematic approach to extracurricular activities, psychological services, improving physical education, which is based on the implementation of individual and differentiated approaches. The head and main coordinator of the formation of a healthy educational space is the director of the educational institution [12].

Health-preserving activity of the future specialist in physical culture and sports provides individual filling and expansion of limits of physical education, functional possibilities of an organism, application of available traditional and non-traditional types, forms, means of individual motor activity; increasing the role of out-ofschool forms of physical culture and sports, ensuring work on the formation of a "healthy environment"; expansion of the sphere of physical culture and health services with the use of opportunities for additional education and means of public support; introduction of a system of rehabilitation psychophysical measures, recreational forms of physical training in the educational process [13].

Note, that in our understanding, the health activities of physical education teachers at school are based on the principles of rational combination of mental and motor loads of students in the learning process. This approach ensures the use of all opportunities for the use of physical exercises during the educational process, on breaks between classes, after school hours, etc. At the same time it is necessary to solve the problem of active recreation, which relieves fatigue from educational activities. Exercise is selected in such a way, that at the beginning of the school week, after a weekend break, they promote the development of speed and strength. In the middle of the week, during the period of high efficiency, speed and strength exercises and dexterity exercises are selected. At the end of the week, against the background of signs of fatigue, it is recommended to use exercises, that develop endurance. Such qualities as flexibility need to be paid attention to throughout the week [14].

The analysis of scientific works on the training of future specialists in physical culture and sports made it possible to show that the definition and verification of the structural components of training is a key issue for researchers.

\section{The purpose and objectives of the study}

The purpose of the study was to experimentally test the formation of levels of the readiness of future professionals in physical culture for health preservation of students.

To achieve the set goal, the following tasks were to be performed:
1. To establish the levels of the readiness of the subjects by motivational, cognitive, activity, creative and organizational-educational criteria;

2. To conduct a factor analysis of the structural components of the readiness.

\section{Research methods}

Analysis and generalization of theoretical provisions of scientific literature were used to solve the set tasks and achieve the goal; questionnaires; testing; pedagogical experiment to test the effectiveness of the formation of structural components of the training of future specialists in physical culture for health preservation of students; methods of mathematical statistics and factor analysis.

The research was attended by students of the first (bachelor's) level of higher education OPP Secondary Education (Physical Education), specialty 014 Secondary Education (Physical Education) of Ushinsky University, from whom information consent was obtained on participation in the research, they formed a control $(n=27)$ and experimental groups $(n=25)$. The study was conducted during 2019-2020.

\section{The results of the study and their discussion}

The comparative analysis of the results of the final stage of the pedagogical experiment shows, that the training of the studied experimental group is more effective in contrast to the studied control group. Thus, in the control group, the number of students who had a high and medium level of the readiness according to the motivational criterion increased by $5.17 \%$ and $8.70 \%$, who had a low level - decreased by $14.56 \%$. In the experimental group, the number of students who had a high and medium level of the readiness according to the motivational criteria increased by $8.41 \%$ and $11.31 \%$, who had a low level - decreased by $31.54 \%$.

The study showed that in the control group, the number of students who had a high and medium level of the readiness according to the cognitive criterion increased by $5.90 \%$ and $4.11 \%$, who had a low level decreased by $10.12 \%$. In the experimental group, the number of students who had a high and medium level of cognitive readiness criteria, increased by $11.25 \%$ and $15.89 \%$, respectively, which had a low level - decreased by $31 \%$.

According to the activity criteria, in the control group the number of students who had a high and medium level of the readiness increased by $6.22 \%$ and 7.08 $\%$, who had a low level - decreased by $11.4 \%$. In the experimental group, the number of students who had a high and medium level increased by $17.01 \%$ and 24.05 $\%$, who had a low level - decreased by $36.45 \%$.

According to the creative criteria, the number of students who had a high and medium level increased by $9.48 \%$ and $7.44 \%$, who had a low level - decreased by $15.76 \%$. In the experimental group, the number of students who had a high and medium level increased by $22.31 \%$ and $18.45 \%$, who had a low level - decreased by $32 \%$.

According to the organizational and educational criteria in the control group, the number of students who had a high and medium level increased by $7.32 \%$ and 
$8.46 \%$, who had a low level - decreased by $16.31 \%$. In the experimental group, the number of students who had a high and medium level increased by $19.5 \%$ and $20.12 \%$, who had a low level, decreased by $34.26 \%$, respectively.

The structure of the readiness of future specialists in physical culture and sports, who were part of the experimental group for the introduction of experimental methods, for health preservation of students at the end of the pedagogical experiment, is determined by three factors, the total variance of signs. The most significant structural components of the readiness are those that form the motivational and creative components, which is $-28.23 \%$ of the total variance. Two more structural components of the readiness - cognitive and activity explain $-22.97 \%$ of the total variance. Indicators of the formation of organizational and educational qualities are $-24.29 \%$ of the total variance.

The advantage of the research was that all participants of the pedagogical experiment studied in one institute, but had to adapt to the quarantine restrictions that were from time to time in the Odessa region, which could affect the overall result. The results of the formative experiment reflect the state of formation of the readiness of future physical education specialists for health preservation of students at the time of the study. Theoretical provisions and practical developments can be used in the educational process of training future specialists in physical culture for health preservation of students, as well as in the system of postgraduate education to improve the professional competence of specialists in physical culture and sports.
In the perspective of further research, we see the study of the problem of health care with applicants for the second (master's) level of higher education OPP Secondary Education (Physical Education), specialty 014 Secondary Education (Physical Education).

\section{Conclusions}

1. The analysis of the levels of the readiness by the criteria revealed that in the control group the number of students who had a high and medium level of the readiness for the introduction of experimental technologies increased by $6.39 \%$ and $6.67 \%$, who had a low level decreased by $13,33 \%$. In the experimental group, the number of students who had a high and medium level of the readiness for the introduction of health preservation technologies increased by $13.33 \%$ and $17.6 \%$, who had a low level - decreased by $30.93 \%$.

2 . The factor analysis of the structural components of the readiness revealed the most significant components of it - motivational, creative, cognitive and activity components.

3. The analysis of the results of the study shows the effectiveness of the formation of structural components for the training of future professionals in physical culture and sports for health preservation of students; the levels of the readiness of the subjects according to the motivational, cognitive, activity, creative and organizational-educational criteria of future specialists in physical culture and sports for health preservation of students are established.

\section{References}

1. Sushchenko, L. P. (2003). Profesiina pidhotovka maibutnikh fakhivtsiv fizychnoho vykhovannia ta sportu (teoretykometodolohichnyi aspekt). Zaporizhzhia: Zaporizkyi derzhavnyi universytet, 442.

2. Dzhurynskyi, P. B. (2013). Teoretychni i metodychni zasady pidhotovky maibutnikh uchyteliv fizychnoi kultury do zdoroviazberezhuvalnoi profesiinoi diialnosti. Odessa, 43.

3. Currie, C. (1998). Health Behhavior in School-Aged Children :Research protocol for the 1997-98 survey. A World Health Organization Cross-National Study. Edinburgh: University of Edinburgh.

4. Brouwer, B., Berkel, M. van, Mossel, G. van, Swinkels, E. (2015). Bewegingsonderwijs en sport: vakspecifieke trendanalyse 2015. Enschede: SLO, 79.

5. Tsujino, K. (2015). An Outsider'i Vsewpoint of Germany's Teacher Education Reform: What Kind of Influence Was Brought by Teacher Education Standarts. Journal of the International Societi for Teacher Education, 19 (1), 85-96.

6. Orzhekhovska, V. M. (2011). Zdoroviazberezhuvalne navchannia i vykhovannia: problemy, poshuk. Naukovi zapysky NDU yim. M. Hoholia. Psykholoho-pedahohichni nauky, 4, 29-31.

7. Bezkopylnyi, O. O. (2020). Pidhotovka maibutnikh uchyteliv fizychnoi kultury do zdoroviazberezhuvalnoi diialnosti v osnovnii shkoli: teoriia ta metodyka. Cherkasy: ChNU im. B. Khmelnytskoho, 552.

8. Belova, L. V. (2011). Podgotovka buduschikh spetsialistov po fizicheskoi kulture k osuschestvleniiu zdorovesberegaiuschei pedagogicheskoi deiatelnosti. Stavropol, 200.

9. Vashchenko, O. (2006). Hotovnist vchytelia do vykorystannia zdoroviazberezhuvalnykh tekhnolohii u navchalno-vykhovnomu protsesi. Zdorovia ta fizychna kultura, 8 (32), 1-6.

10. Ivanova, L. I. (2014). Teoretychni i metodychni zasady profesiinoi pidhotovky maibutnikh uchyteliv fizychnoi kultury do roboty z uchniamy $\mathrm{z}$ vidkhylenniamy u stani zdorovia. Kyiv, 40.

11. Goraschuk, V. P. (2003). Formirovanie kultury zdorovia shkolnikov (teoriia praktika). Lugansk: Alma-mater, 376. Lutsk, 296

12. Dubohai, O. D. (2011). Osnovni poniattia i terminy zdoroviazberezhennia ta fizychnoi reabilitatsii v systemi osvity.

13. Mikhieienko, O. I. (2015). Pidhotovka maibutnikh fakhivtsiv zi zdorovia liudyny do zasosuvanniazdoroviazmitsniuiuchykh tekhnolohii: teoretyko-metodychni aspekty. Sumy: Universytetska knyha, 316.

14. The Health Promotion School - an investment in education, health and democracy (1997). Denmark: WHO, 37.

Received date 12.08.2021

Accepted date 21.09.2021

Published date 30.09.2021

Petr Dzhurinsky, Doctor of Pedagogical Sciences, Professor, Director, Educational and Scientific Institute of Physical Culture, Sports and Rehabilitation, Government agency "South Ukrainian National Pedagogical University named after K. D. Ushinsky», Staroportofrankivska str., 26, Odessa, Ukraine, 65020 